\title{
Stress as A Basic Concept and Nursing Approaches
}

\author{
Filiz Ersöğütçü and Nurdilan Şener* \\ Faculty of Health Sciences, Department of Nursing, Elazı̆̆, Turkey \\ *Corresponding author: Nurdilan Şener, Faculty of Health Sciences, Department of Nursing, Elazığ, Turkey
}

$\overline{\text { ARTICLE INFO }}$ ABSTRACT

Received: 豐 September 29, 2019

Published: 慧 October 11, 2019

Citation: Filiz Ersöğütçü, Nurdilan Şener. Stress as A Basic Concept and Nursing Approaches. Biomed J Sci \& Tech Res 21(5)-2019. BJSTR. MS.ID.003669.

Keywords: Stress; Stress Management; Nursing
Stress is a state of reaction to a person's impairment of biological and psychological balance. As an inevitable consequence of life, all living creatures experience stress. Stress is a state of change that occurs automatically as a result of physical, mental and emotional stresses that causes positive and negative emotions and has physical and mental effects. There can be many sources of stress. The environment we live in, our body, our thoughts, and even how we see the world can be a stress factor. When we understand how individuals react under extremes of stress, many of the more subtle and unstretched forms of behavior will be immediately understandable. Stress is the defense mechanism of human being. In response to emotional or physical stress, the human body causes a complex physiological response that is known and yet not fully understood. It is important to understand the biology of the stress response and when it becomes pathological. Stress has multidimensional effects. Stress related symptoms can be grouped into four as physical, emotional, mental and social. There are some specific symptoms of stress.

These symptoms include constant anxiety, excessive alcohol consumption and smoking, insomnia, difficulties in co-operation, feelings of inadequacy, emotional imbalance, digestive problems, high blood pressure. In order to cope with stress and improve the quality of life, changing the state or reactions is called stress management. Stress upsets the entire balance of the individual. It is possible to cope with stress by using the individual's own power with mental regulations and new conditionings, by teaching the stress-relieving body and mind relaxation exercises. A nurse is a health professional who provides support for stressed individuals. Nurses are important help providers in providing professional knowledge and skills and supportive interventions to stressed individuals. Nurses provide psychological counseling and guidance services to recognize stressor that causes stress to eliminate stress in the environment, to protect and maintain mental health of individuals, to teach effective ways of coping with stress.

\section{Stress as A Basic Concept and Nursing Approaches}

Stress is one of the most important areas of human understanding. When we understand how individuals react under extremes of stress, many of the more subtle and unstretched forms of behavior will be immediately understandable. Stress is the reality of life, but contrary to popular understanding, stress is not always a bad thing. Indeed, the capacity to adapt to and respond to various conditions of existence can be a definition of life itself [1]. According to APA's 2015 stress report in the USA, 78\% of the population reported that they experienced stress symptoms [2]. Stress was named as "health epidemic of 21st century" by the world health organization [WHO] [3]. Stress is defined as "an attack that threatens the existence of organisms with all kinds of factors and the reaction of the organism to this attack". Stress has been the subject of research by many of the researchers and it has been tried to be defined with different expressions.

Research and evaluations explaining the relationship between stress and human were made by Hans Selye for the first time. The term stress was defined as "nonspecific response of the body to any demand and these responses may be acceleration in the heartbeat, dry mouth, tremor, restlessness, excessive fatigue" by Selve [4]. According to Cüceloğlu, stress is "the effort an individual spends beyond the physical and psychological limits due to the inconvenient conditions in the physical and social environment [5]. All people feel stressed. In response to emotional or physical stress, 
the human body causes a complex physiological response that is known and yet not fully understood. Stress creates a response through the autonomic nervous system and the hypothalamicpituitary-adrenal axis to activate various areas of the brain through mediators such as dopamine, serotonin and others. It is important to understand the biology of the stress response and the time it becomes pathological [6].

Stress is divided into constructive stress "eustress" and destructive stress "distress". Constructive stress can arise from vital difficulties caused by pleasant activities. Destructive stress can arise when there are unpleasant situations that need to be adapted [3]. Stress has multidimensional effects. Anxiety, tension, restlessness, fear, embarrassment can be seen in emotional dimension; self-criticism, concentration and decision-making difficulty, forgetfulness, thoughts about failure in intellectual dimension; stuttering or similar speech difficulties, crying, irritability, clenching teeth, increased or decreased appetite in behavioral dimension; tension in the hands, sweating of hands, headache, back or neck problems, frequent sickness, feeling of fatigue, rapid breathing, palpitations, tremor in physical dimension [7-9]. Stress factors can be caused by the person or his/her environment. Individual stress sources are formed by individual needs, capacity and character. Differences in perception, experiences, family problems, relations between family members, upbringing, education, spouses bringing their work problems to home, divorce and death are factors that create individual stress [10]. Environmental stress sources are stress sources related to the general environment of the individual and stress sources other than business life. Family problems, economic difficulties in the country and the world, a monotonous lifestyle, socio-cultural changes and transportation problems are important stress factors related to the general environment [11]. Work-related stress sources are related to the stressful work environment, shift work, too much or too little work, physical danger, adaptation to one's environment and work/ family relationships $[12,13]$. Threatening of the organism, and therefore a disturbance of the balance, causes an alarm response to maintain vitality. In order to restore the deteriorating balance, it is necessary to adapt to the new situation [14]. This adaptation sign has three steps, the first step is the alarm reaction, that is, when the organism perceives the external stimulus as stress. In this period, the organism goes into shock and countershock [15].

The second step is the resistance period. This period is suitable for adaptation against stressful conditions, that is, the resistance of the body increases above normal during this period. At this stage, the individual puts all his or her effort to resist the stress and shows the behaviors of a stressed person [15]. The third step is the exhaustion period. If the stressful event is very serious and lasts a long time, the exhaustion stage comes out. Sometimes during this period, re-alarm period reactions occur. Each creature's adaptability and energy are different and limited. Sleep and rest can repair the body, but in the face of ongoing and unmanageable stresses, the balance is disrupted, and the energy of harmony ends [15]. Stress management is defined as a process that minimizes stress by enabling the person to use an appropriate and effective coping method when confronted with psychological stress that puts the person under pressure. This process is all positive or negative efforts. Stress management includes techniques for managing conditions, spending effort to solve personal and interpersonal problems, managing, minimizing, reducing or tolerating stress or conflict, and enabling the individual to lead a happier, healthier, productive, mentally and behaviorally balanced, quality life.

Since coping methods may vary according to personality traits, it is very important to try and learn the most appropriate one for the person. In the struggle to cope with stress, the step that will enable us to take half of the way is to recognize the individual stress response. There are several methods for stress management. These methods can be grouped as physical methods, mental methods, behavioral techniques, seeking social support and the 4 A's Model [Avoid, Alter, Adapt and Accept] in stress management [16-20]. A nurse is a health professional who provides support for stressed individuals $[21,22]$. Interventions that can be applied by nurses in case of stress are evaluation of stress causing factors, explaining ways of self-appeasement when got angry, giving advice to think about things that are pleasing, teaching deep breathing exercises for relaxation, recommending to participate into different activities that make happy, determining what is important in life and what needs to change, planning these changes weekly, helping to create realistic goals for achieving a healthy lifestyle, referring to a professional counselor if the person has severe depression or anxiety or to a family counseling if the person has intense family problems [23].

\section{References}

1. Hancock P, Szalma J (2018) Stress and Performance. Performance Under Stress: Crc Press 17-34.

2. American Psychological Association (2016) Stress İn America: The İmpact Of Discrimination. Stress İn America Survey, Washington DC.

3. Brulé G, Morgan R (2018) Working with Stress: Can We Turn Distress İnto Eustress. Journal of Neuropsychology \& Stress Management 3: 1-3.

4. Ivanovic J (2018) Hormones and Metabolism İn İnsect Stress: Crc Press.

5. Cüceloğlu, Doğan (2000) İnsan Ve Davranıșı. İstanbul: Remzi Kitabevi.

6. Cool J, Zappetti D (2019) The Physiology of Stress. Medical Student Well-Being: Springer Pp: 1-15.

7. Townsend Mc (2016) Psychiatric Mental Health Nursing: Concepts of Care Translation: Özcan Ct, Gürhan N. Academician Bookstore, Ankara.

8. Çam O, Engin E (2014) Ruh Sağlığı Ve Hastalıkları Hemşireliği Bakım Sanatı. İstanbul Tıp Kitabevi.

9. Gürhan N (2016) Mental Health and Psychiatric Nursing. Ankara Nobel Medical Bookstore.

10. Gümüștekin Ge, Öztemiz Ab (2005) Productivity and Performance Interaction with Stress of Organizations. Çukurova University Institute of Social Sciences Journal 14(1): 271-88.

11. Haşit G, Yaşar O (2015) Organizational Stress Sources Among Working Women: A Public Agency Pattern. The Sakarya Journal of Economics 4(4): 1-30. 
12. Göksel A, Tomruk Z (2016) The Relationship Between Academics' Stress Sources and the Behaviors of Coping with Stress and In Case of Stress. Turkish Journal of Social Research 20(2): 315-343.

13. Al-Gamal E, Alhosain A, Alsunaye K (2018) Stress and Coping Strategies Among Saudi Nursing Students During Clinical Education. Perspectives İn Psychiatric Care 54(2): 198-205.

14. Çatal E, Dicle A (2014) Component: Example of Roy Adaptation Model. Dokuz Eylül University Faculty of Nursing Electronic Journal 7(1).

15. Gençöz, F (1998) Adjustment Psychology. Kriz Journal 6(2).

16. Okutan Um, Tengilimoğlu D Stress in Business Environment and Methods for Coping with Stress: A Field Practice.

17. İștar E (2012) The Relationship Between Stress and Productivity. Akademik Bakış Dergisi 33: 1-21.

\section{ISSN: 2574-1241}

DOI: 10.26717/BJSTR.2019.21.003669

Nurdilan Şener. Biomed J Sci \& Tech Res

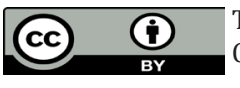

his work is licensed under Creative Commons Attribution 4.0 License

Submission Link: https://biomedres.us/submit-manuscript.php
18. Crampton Sm, Hodge Jw, Mishra Jm, Price S (1995) Stress and Stress Management. Sam Advanced Management Journal 60(3): 10.

19. Braham Bj (1994) Managing Stress: Keeping Calm Under Fire: Irwin Professional Pub.

20. Yasemin Ö, Karabulut Ab (2018) Daily Life and Stress Management. Journal of Medical Sciences and Research in Turkey 1(1): 48-56.

21. Yllmaz T, Oskay Üy (2015) Coping with infertility stress and nursing approaches. Journal of Health Sciences and Professions 2(1): 100-112.

22. Arslan Bș, Buldukoğlu K Is it Possible to Grow from the Mental Illness Experience? An Assessment From the Psychiatric Nursing Perspctive. Sakarya University Journal of Holistic Health 1(1): 16-27.

23. Judith M, Wilkinson Laurie Barcusn (2018) Nursing Diagnosis Handbook, Pearson.

$\begin{array}{ll}\text { BIOMEDICAL } & \text { Assets of Publishing with us } \\ \text { RESEARCHES } & \text { - Global archiving of articles } \\ & \text { - Immediate, unrestricted online access } \\ \end{array}$

